\title{
La Iglesia como promotora del legado artístico virreinal
}

\author{
Martha Barriga Tello \\ Departamento Académico de Arte
}

A partir del siglo XVI fueron diversas las modalidades por las que los templos y conventos católicos en el Perú fueron edificados y cubiertos de obras de arte. Las formas de fábricación y de adquisición tuvieron que ver tanto con la donación -espontánea o inducida-de los diferentes estratos de la sociedad virreinal, como por la directa intervención del estamento religioso.

Es a partir de ello que podemos analizar las formas de patrocinio de la Iglesia en el Perú en su afán de cimentar su patrimonio artístico. No abordaremos en esta oportunidad la intervención de la Iglesia como mecenas, investigación que realizamos paralelamente a ésta, sino solamente como propulsora de donaciones, tanto de la sociedad civil como de los religiosos.

Uno de los medibs por los que llegaron las abras que constituyeron patrimonio de la Iglesia en todo el territorio del Virreinato peruano fue el equipaje de los primeros expedicionarios españoles, religiosos y civiles.

Entre los religiosos encontramos al mercedario Juan de Chávez, quien en 1535 solicitó y obtuvo, se le favoreciera con algunas imágenes destinadas a la misión que emprendería en América. El Tesorero de la Contaduría de la Contratación pagó a "Jorge Hernández, entallador, 6,000 maravedises por la hechura de un crucifijo grande, de bulto, de madera, que hizo a una imagen de Nuestra Señora con el Niño Jesús, para llevar a Santa María el dicho P. Juan de Chávez" y a "Antón Sánchez de Guadalupe, pintor y dorador se le dieran otros 6,000 ms. por la pintura y dorado de las mismas". El padre Chávez falleció, lo que derivó que las obras se asignaran a su compañero de Orden, Fray Miguel de Orenes, quien fue destinado al Perú, lo que hace muy probable que las piezas fueran entregadas al convento de La Merced en Lima (Vargas Ugarte 1968:100).

LETRAS (Lima), 94: 3-24,1997. 
En oportunidades era el viajero civil el que incorporaba a su equipaje alguna imagen que lo protegiera en la incierta travesía. La pintura de "La Virgen de Rocamadur" se ha sindicado como la obra más antigua de este grupo existente en el Perú (Stastny 1985). Muchas de estas obras fueron posteriormente donadas a los templos como exvotos. Otras formaron parte de los bienes de difunto o permanecieron en custodia en las iglesias rurales o en oratorios particulares.

Más tarde, cuando se instituyó la Iglesia y fueron enviadas las autoridades a las principales sedes del Virreinato, entre los objetos personales que llevaron consigo, figuraban obras de arte piadoso. En 1542, cuando a raíz de su muerte se levantó un inventario en Lima de los bienes del Obispo Fray Vicente de Valverde, se consignó "una ymagen de lienço... vna ymagen grande [de la] Verónica... vna y magen con vnos corporales dentro... vn retablo de marfil con vna ymagen de Nuestra Señora dorado/otras dos ymágenes, en vna tabla anbas... vn retablo pequeño de Crucifijo... (Hampe 1981:142-144). Todos ellos objetos que en mayor o menor número se encontraban indefectiblemente en el menaje de los religiosos.

En su mayor parte constituían su patrimonio personal, pero tambièn hubo ocasiones en las que le habían sido encargadas por terceros que confiaban en su capacidad para elegir las adecuadas. Un caso de éstos sucedió con los vecinos de Limia, qưientes con ocasión del primer viaje que realizó Vicente de Valverde a España en 153417e entregaron una suma de dinero a fin que comprara ornamentos para la nueva catedral. En 1538 regresó fray Vicente convertido en Obispo de la sede en la ciudad del Cusco. Los ornamentos que le encargaron comprar para la catedral de Lima los llevó directamente al Cusco, lo que le valió una reconvención del rey ante la queja de los afectados (Lissón Chávez 1943-1946, II [20.IX. 1539]).

En otra situación encontramos a Fernando de la Cueva, nombrado Obispo de La Plata. Cuando partió a su destino desde Sevilla en 1560, llevaba consigo "cuatro piezas de retablo", que le había encomendado vender a su paso por el Perú, el artista Roque de Balduque. Problemas suscitados en Panamá lo obligaron a rematarlas allí. En esta ocasión el Obispo actuó de "comitente", o de intermediario, en la venta de obras de arte.

También llegaron al Perú obras de arte como bien propio y para uso particular. Este fue el caso de las autoridades eclesiásticas, quienes 
como Vicente de Valverde, debieron trasladarse con menaje suficiente para el tiempo de su estadía. El segundo Arzobispo de Lima, Toribio Alfonso de Mogrovejo -quien asumió sus funciones en Lima el 11 de mayo de 1581antes de emprender el viaje hacia su sede, decidió hacer algunas compras de elementos que consideró indispensables para su nuevo cargo. Al efecto tomó como fiadores a tres vecinos de Sevilla: Francisco Martínez López, Diego Díaz Becerril y Juan Alonso de Medina, con quienes acudió ante Lorente de Santantón. Mogrovejo pagó “un quento e dozcientas e conquenta y seys myll e trezientos e veinte e cinco maravedis" por las siguientes piezas:

\author{
"un jarro de plata sobredorado; \\ una taza de plata alta sobredorada; \\ otra taza de plata sobredorada çercadilla, \\ una taza lisa de plata çercadilla, \\ un salero de tres servicios liso blanco de plata dorada; \\ un jarro de plata dorado, enano; \\ dos candeleros blancos de plata romeados; \\ una fuente blanca de plata dorada zercada con un festón \\ con unas armas en medio, un arbol y capelo; \\ una taza de plata dorada con un medallón al centro; \\ un cofre de plata con sus tornillos y un unicornio; \\ un plato de manjarillañoteca de Letras \\ una fuente de plataun poce quebrada en las orillas; \\ quatro platos de manjar de plata quebrados.
}

De oro: una cadena; un mondadientes; un crucifijo y un papagayo de oro;

Cinco anillos de esmeraldas;

2 mil arrobas de azeite, una saya verde de terciopelo con raso y tela de oro aun no; acabada

una saya de raso blanco no acabada con su acera y mangas de punta mas tela de plata y forro de seda encarnado;

Doce arcabuceros de Holanda; cinco paños de tapicería de bosorge"

Estos objetos completaron una compra previa de " ciertos doseles de damasco verde" por la suma de 171,429 maravedíes (Catálogo 1930, 1: 495504 [s.XVI, Doc. 1687]). Constituye esta relación una referencia de lo que debió ser el equipaje de un prelado, aunque en este caso notamos cierto apresuramiento en incorporar piezas inacabadas y maltratadas, así como fuentes que llevaban "unas armas", aludiendo a un posible dueño anterior. 
Tenemos información de prelados nombrados a las sedes americanas que repartían los ornamentos que formaban parte de sus equipajes, entre los pueblos por los que pasaban. Tal fue el caso del Obispo del Cusco don Fernando de Mendoza, quien a principios del siglo XVII entró a su Obispado y entregó los que llevaba "de suerte que llegó al Cuzco con un solo ornamento, y después, habiéndole enviado de España cerca de mil varas de damascos y terciopelos para una colgadura de su casa, considerando la falta de ornato de las iglesias de los indios, las mandó gastar todas en ornamentos". Otro tanto hizo Santo Toribio de Mogrovejo, "cuando volvía de la visita no traía nada de su pontifical, que todo lo dejaba de limosna, y porque en Moyobamba no tenían cruz para las procesiones les dejó la cruz de su guión, y hoy la tienen y estiman como es razón" (Arriaga 1968: Cap. XI).

No solamente la alta jerarquía tenía la preocupación de premunirse de objetos ornamentales y de culto. Los miembros de las congregaciones religiosas enviados al Perú en el siglo XVI, tuvieron la precaución de embalar algunos lienzos e imágenes que fueron utilizados seguidamente como apoyo para la evangelización. Constituía este un recurso eficaz en cuanto suplía el mensaje oral o, cuando menos, lo orientaba en su correcta comprensión. Las prédicas iniciales se hacían en castellano y, en el mejor de los casos, por medio de intérpretes. La traducción de los textos a las lenguas vernáculas, y el aprendizaje de éstas por los religiosos, fue ún procesolente y Tleno de dificultades.

\section{"Jorge Puccinelli Converso»}

Un doctrinero, necesariamente debía proveerse de gran cantidad de cálices, ornamentos, imágenes, cruces y rosarios, antes de emprender viaje hacia América. En ocasiones estos objetos le eran asignados por disposiciones oficiales -como al mercedario Chávez- pero en otras, los adquirió de su peculio, como evidencian los casos de Vicente de Valverde o Toribio Alfonso de Mogrovejo. Entre las imágenes el religioso debía contar con lienzos para la prédica masiva, esculturas en bulto para conformar altares, e imágenes portables para distribuir entre sus oyentes. Consideremos la extensión del territorio del Virreinato del Perú, el número de pueblos y la cantidad de indígenas y españoles a quienes servir, para comprender la dimensión del fenómeno, sólo en lo referente a los doctrineros, sin considerar las corporaciones religiosas ni las necesidades de la alta jerarquía (Barriga Tello 1993:108 ss).

Una medida en esta dirección se constata en el caso frecuente de 
religiosos que asumieron diversos oficios por disposiciones superiores, o que fueron trasladados desde Europa u otros lugares americanos, exclusivamente para ejercerlos. En una carta del Rector del Colegio Jesuita del Cusco, P. José Teruel, aparece que en dicho local residían Padres y Hermanos artífices, todos los cuales habían participado en la edificación y adorno de la primera iglesia de la Orden en la ciudad, recurriendo para ilustrarse a libros sobre la materia y a consultas con personas entendidas. (Vargas Ugarte 1963: 66-67). Quede este ejemplo como evidencia de la voluntad de los religiosos en acometer con responsabilidad la empresa para lo que procuraron, incluso, contar con tratados especializados que orientaran su quehacer, tal como era práctica común entre oficiales laicos.

Aparte del trabajo comunitario, los religiosos debían enfrentar su capacidad apostólica recorriendo los pueblos y congregando "infieles". Para influir la aceptación de éstos se llamó la atención sobre ciertas pautas consideradas indispensables. Aún en el siglo XVU se insistía en la conveniencia de que después del catecismo, los días domingo, se repartieran "premios" de rosarios e imágenes a los indios que hubiesen respondido correctamente las preguntas del doctrinero (Arriaga 1968: Cap. XIII; Armas Medina 1953: 345). Esto suponía viajar premunido de suficientes objetos que entregar.

El aporte del roligiosioe ra ireposible que cabriera la demanda que necesariamente habría de preducirsen. Durante laprédiça éste debía exhortar a los asistentes a portar sus propias imágenes y rosarios: “...y se les enseña a que los hagan de la chaquira gruesa que suelen traer por ornato al cuello las mujeres, o que los hagan de cordeles y ñudos como quipos, aunque los más los envían luego a comprar donde los hallan. Y me decía un español que no había él menester mejor granjería que irse tras los padres vendiendo rosarios entre los indios" (Arriaga 1968: Loc. cit.)

En esta información destacan dos aspectos. En primer lugar resulta revelador que, sin proponérselo -e incluso buscando un resultado opuestolos frailes incentivaran la práctica del uso de la chaquira o de los quipus en la confección de rosarios, precisamente alentando la permanencia de costumbres que se intentaba erradicar. Hecho que puede comprenderse si la pretención fue -como en otros casos- desvincular el elemento indígena de su contexto, desnaturalizándolo. Por otra parte, se advierte que el tránsito del religioso organizaba a su alrededor un próspero negocio de objetos piadosos, el mismo 
que reportaba ganancias para el mercader y para el artesano implícito en la producción. Este circuito, tangencialmente, sugiere la función de promotora indirecta de objetos de arte religioso que compitió a la Iglesia durante la época virreinal. Igualmente supone un cliente en el religioso y en el indígena, además de otros grupos relacionados circunstancialmente. Observamos en la cita del padre Arriaga que "los más"de los indígenas, preferían no aceptar la sugerencia del doctrinero, sino comprar objetos específicos, preservando de esta manera, la validez de los materiales nativos para usos tradicionales. Esta actitud de aceptar pero no internalizar los efectos de la cristianización, es uno de los fenómenos más interesantes de esta época.

Una forma ingeniosa que propició el mercado de obras de arte por parte de la Iglesia - además de contribuir al adorno de los templos- fue la modalidad de condonar penas por diversos delitos a cambio de contribuir a la construcción y adorno de los templos. Esta sentencia afectó por igual a indígenas y españoles, a civiles y religiosos.

A los implicados en el movimiento del Taki Onkoy (1560-1570), se les condenó a hacer en un año "todos ellos la iglesia mayor de este pueblo y provincia de Atunsora, y que el cuerpo de la dicha iglesia lo hiciesen todos de comunidad con los indios porque también eran culpados y que la madera clavazón de puertas y cerrrojôsla comprasen los dichos caciques de sus haciendas y así mismo parece fueron condenados a cien pesos de plata corriente aplicados para un ornamento de la dicha iglesia " tal como apareció en la información de Cristóbal de Albornoz (Millones 1984: 12; Stern 1982: 63). Los curacas cumplieron esta condena con la partipación de los indios de sus corregimientos, la misma que se tradujo en un edificio y la compra de un ornamento en beneficio de la iglesia del lugar.

Este sistema se aplicó igualmente a los religiosos.El ya mencionado obispo del Cusco Fernando de Mendoza , a fin de perdonar deudas o paliar castigos que por cometer delitos comunes les había aplicado, los obligaba a entregar un ornamento a alguna iglesia. Para no mellar la respetabilidad del implicado, permitía que figurara a manera de donación, incluso consintiendo que grabaran sus iniciales en él (Arriaga 1968: Cap. XI). Consideradas las circunstancias en que se desenvolvía la vida de este estamento durante los primeros años del siglo XVI, la costumbre debió ser fuente de importantes adquisiciones dentro de la jurisdicción eclesiástica. 
También los artistas se encontraron incursos en amonestaciones de diversa índole en caso de no cumplir las estipulaciones señaladas en los contratos que firmaban. Pedro de Santángel en 1586 suscribió un concierto para realizar un trabajo para la Cofradía de la Virgen de la Soledad en la iglesia de La Merced en el Cusco, en el que se especificaba que "si dentro de los dichos quarenta días no acabase la dicha obra, pierde veinte pesos y se queden para limosna de la dicha cofradía "(Cornejo Bouroncle 1960:166). Desde 1535 en Lima también se aplicaron multas a favor de las fábricas. Suponemos que en el caso cusqueño la obra quedaría en poder de los cofrades ya que se había cancelado parte de ella. En otros casos la pena suponía que el artista debía asumir el pago de una obra similar por otro artífice, a satisfacción del comitente religioso. Esta estipulación era común también en los contratos con civiles.

Los religiosos fueron promotores voluntarios e incondicionales en la adquisición de obras de arte. El P. jesuita Joseph de Arriaga cuenta que un doctrinero iba predicando de pueblo en pueblo procurando, una vez finalizada su labor, dejar las iglesias "reparadas [proporcionadas] de ornamentos e imágines, y de todos los pueblos envía dineros para este efecto, y el día de hoy tengo dineros que me ha enviado para compralle diversas cosas que faltaban en las iglesias de cuatro pueblos. Y de su propio dinero, que me remitió para ello, le compré y envié grand cantidad de rosarios, que va repartiendo entre los indios" (Arriaga 1968: Cap. XP). Este infornedacoentąe la colaboración existente entre compañeros de profesión, apoyándese encel trabajo,emprendido. Pone de manifiesto, igualmente, un aspecto interesante de recalcar. Arriaga parece sorprenderse de que este cura utilice "su propio dinero" para efectuar dichas compras, las que, añade, fueron "en grand cantidad". Podría suponerse que el religioso contara con una renta distinta a la correspondiente a su manutención, conocido que era escasa, o que en su defecto dispusiera de fondos que no le pertenecían. No era extraño que un religioso administrase dinero de una comunidad para invertirlo en ornamentos. Este fue el compromiso de fray Bartolomé de la Cerda, cura del pueblo de Leviataca, quien "en nombre del común del dicho pueblo" encargó a Pedro de Santángel tres imágenes en bulto de Nuestra Señora de la Asunción, Santa Bárbara y Santiago "doradas y pintadas en la forma acostumbrada" por un valor de 450 pesos (Covarrubias Pozo 1958: 300; Cornejo Bouroncle. 1960: 332: [Pt. 792/33ff. 446. Escrib. Jerónimo Sánchez de Quesada]), cifra nada despreciable para la época.

Si las doctrinas despertaban la exaltación del religioso, no menor 
respuesta suscitaron las sedes urbanas, centros ostensibles de la fe cristiana. A fray Domingo de Santo Tomás, célebre personaje en su época, se debió el encargo al taller sevillano de Roque de Balduque en 1558, de una Virgen del Rosario que aún se conserva en su apariencia original gracias a un proceso de restauración realizado en 1985. Esta donación demuestra la constante preocupación de fray Domingo por su convento en Lima, considerando que por entonces residía en España (Arévalo 1970:103; Bernales Ballesteros 1991: 27; Vargas Ugarte 1956: II, 80). Sobre esta escultura se menciona que en la documentación del virrey Mancera aparece como la primera en la fundación y conquista del Perú (Bernales Ballesteros 1991: Loc. cit.) Años después, en 1562, cuando decidió aceptar el Obispado de La Plata y en camino hacia allí, se dice que Domingo de Santo Tomás ordenó erigir una iglesia, de su peculio, en el pueblo de Paucarcolla, haciendo otro tanto al llegar a Chuquiabo ( $\mathrm{La} \mathrm{Paz}$ ), contribuyendo con parte de su renta para terminar la iglesia. (Porras Barrenechea 1951).

La obra de arte se convierte en símbolo de la compenetración que los frailes, especialmente los que vieron crecer los monasterios americanos, tuvieron con sus sedes iniciales. Muchos otros ejemplos se mencionan respecto a la actitud de los religiosos como promotores en la adquisición de obras para sus conventos y centros misionales, tanto más en los primeros años del siglo XVI en los que, por lo general, carecían de lo elemental. Es el caso del ardor constructivo de fray Tornás de San Mattín parata misma iglesia dominica en Lima y sus dependengiass genventuåles (Lizárraga 1968: Libro II, Cap. XLIX). Las de reconstrucción emprendidas por los distintos priores para reedificar lo que los terremotos se encargaban de destruir. La del Arzobispo de Lima, Toribio de Mogrovejo, quien pagó de su peculio una imagen de Nuestra Señora de Belén a Mateo Pérez de Alesio (Stastny 1969: 18).

Igualmente importantes como fuente de recursos en favor de las iglesias y conventos fueron las dotes entregadas por monjas y novicias en los distintos conventos. La iglesia del de La Encarnación en Lima, fue edificada en 1583 con un gasto de 50,000 pesos que se obtuvieron de esta procedencia (Vargas Ugarte 1968: 88). Durante esta etapa de la época virreinal cada logro se orientaba a constituir la infraestructura indispensable al establecimiento de la Institución. En la medida que ésta se resolviera se aplicaba los gastos a embellecimiento y ornato.

No solamente eran de interés las grandes edificaciones, los templos 
y conventos. Las capillas y los hospitales fueron igualmente favorescidos en cuanto al interés que la Iglesia mostrara en ellos. Fray Jerónimo de Loayza, primer Arzobispo de Lima, compró el terreno y edificó el hospital de Santa Ana para servicio de los indios, en el cual fray Domingo de Santo Tomás "hizo y dotó" una capilla (Córdoba y Salinas 1958: 39 y 57; Lissón Chávez 1943-1956: 2, $\mathrm{N}^{\circ}$ 8) para la que obtuvo del Papa Paulo IV un jubileo perpetuo (Porras Barrenechea 1951). Toda contribución parecía insuficiente para dotar cada una de estas dependencias a fin de elevarlas a la categoría de la sociedad a la que servían de marco, prestigiada por sus símbolos externos.

La tasación presentada por Jordán Fernández Lobo de la obra de pintura que realizó a instancias del Arzobispo Loayza en 1564, nos da una idea del aspecto y valor del referido hospital. En ella afirmaba " que antes va tasado menos de lo que parece, que no más", añadiendo, "Las pinturas de la puerta principal con el escudo y lo demás vale 110 pesos; los escudos que están en la iglesia sobre el sagrario y el otro vale la hechura, 10 pesos; la pintura de la enfermería grande la cenefa y la pintura que está en el altar vale la hechura, 65 pesos; seis historias que están pintadas en el claustro de las obras de misericordia, 40 pesos; la pintura que está en el oratorio en el corredor alto vale la hechura, 80 pesos; la pintura que está en el altar de la enfermería de las mujeres y lo del zaguán vale la hechura 15 pesos". Reportaba además 320 pesos por tododel trabajo, đo que indudablemente era precio razonable para este p̈intorided que pocosesconoce. (Lissón Chávez 1943-1956: Loc. cit.).

Más activo fue Gaspar Báez, quien llevó a efecto la rendición de cuentas de los trabajos de albañilería que realizó en el mismo hospital.Trabajó en colaboración con Alonso Gonzales Beltrán, ambos "estantes en la ciudad de los Reyes". Acerca de la enfermería nueva, declaran que contaba "con un corredor y ciertos suelos de solería de unas piezas altas del dicho corredor de manos de nos los dichos albañiles ladrillo y cal y adobes y poyos y encalar y en blanquear la enfermería en 1,200 pesos de oro en plata ensayada e marcada de valor cada un peso de 450 maravedís y esto nos parece que merece la dicha obra en Dios y en nuestras conciencias y en ello no hay fraude ni engaño y lo firmamos de nuestros nombres" (Loc. cit.). El esfuerzo del Arzobispo Loayza fue retribuido por los Hermanos 24 del Real Hospital de Santa Ana cuando le dieron sepultura en la capilla mayor del templo, encargando al efecto retratos suyos en escultura y pintura (Córdoba y Salinas 1958: 37). 
Relacionada al culto que surgió alrededor de la Virgen de Guadalupe en el Perú, encontramos una donación particular en la que consignamos la contribución formal de la Iglesia. Ocurrió en Lima, cuando el monje jerónimo fray Diego de Ocaña, no sólamente se limitó a incentivar la fundación de una capilla dedicada a la Virgen en las afueras de la ciudad, sino que se ofreció a pintar una imagen representándola en un cuadro que fue posteriormente colocado en el altar principal de los tres que la ornaban. Este local pasó luego a manos de los franciscanos, quienes en basc a diversas donaciones, levantaron un templo (Vargas Ugarte 1956: II, 106 y ss.).

Igual actitud tuvo el padre agustino fray Agustín de la Trinidad, de ser el autor de la obra escultórica que representaba a Nuestra Señora de la Gracia, Patrona del convento de San Agustín en Lima (Vargas Ugarte 1968: 139). También fue una escultura, esta vezz del Niño Jesús sobre andas de plata, la que se menciona que realizaron los Hermanos Bernardo Bitti y Mosquera para la cofradía de los indios en la iglesia de la Compañía de Jesús en el Cusco. Entendemos que a modo de donación porque esta cofradía era apoyada por la Orden y porque los indios habian llevado la piedra y la madera desde lugares muy distantes para la construcción de la capilla que se les había asignado (Mesa y Gisbert 1974: 45; Vargas Ugarte 1963: 67).

Los indígenas ho fueton, exclusivamente, depositarios de donaciones, sino que acudierōn frecữenternentẻ contribayendo con servicios, o con adquisiciones, de obras de arte en favor de la Iglesia en razón de la atención que pusieron en ello los religiosos, quienes debían valerse de "pinturas y otras figuraciones" para instruir a los neófitos.

Una forma de donación fue en ornamentos. Era la opinión que "la falta de ornato en las iglesias más proviene de la falta de curiosidad de algunos curas que no de la falta de plata, porque fuera de lo que saca de los tributos de cada año para la iglesia que los indios acuden con facilidad a semejantes gastos, o haciendo algunas chácaras para este efecto, o de otras maneras si hay quien los aliente a ello. Y así pueblo ha habido donde en una tarde juntaron los indios más de trescientos y cincuenta pesos para comprar pendón y cruz de plata, y una hechura de un Niño Jesús, y otras cosas necesarias para una cofradía que se les había instituído" (Arriaga 1968: Cap. XI). Conjuntamente, los indios y el doctrinero, debían aunar esfuerzos para conseguir logros corporativos pues, igualmente, se conmina a que se invierta las rentas obtenidas por los 
tributos. A nivel comunal y como acción vecinal, el padre Rodrigo Hernández mencionaba la "liberalidad" con que la población de Quepas juntó el dinero suficiente para comprar un dos el, un cielo, " $y$ un santo para su pueblo, cuyo patrón es San Juan Bautista" (Arriaga 1968: Cap. X y Jesuita Anónimo 1968: 188). Recordemos aquí el encargo que recibió Fray Bartolomé de la Cerda para el pueblo de Liviataca.

Respondiendo a diversas motivaciones, entre las que destacaban la demostración de capacidad adquisitiva, de poder social y político, añadidas a las de piedad religiosa, los curacas concurrieron con espléndidas donaciones para los templos. Don Jerónimo Guacrapáucar, curaca de los Luringuancas, aliados de los españoles en la derrota de Atahualpa, dispuso que sus yanaconas edificaran una iglesia en el pueblo de Tunán, bajo la advocación de San Jerónimo, el que posteriormente dio el nombre por el que se conoció la comarca. Gaucrapáucar la dotó de ornamentos e imágenes, entre las que destacaba la talla del santo titular. Quedaba sídemostrada la importancia del comitente y su prreminente vínculo con la Iglesia. Este templo y el convento adyacente, quedaron en poder de los franciscanos asentados en la zona (Espinoza Soriano 1977: 247).

Las contribuciones, además de implicar un mercado artesanal al cual era posible acudir, dancuentade ta adhesion destos pueblos al proyecto de la

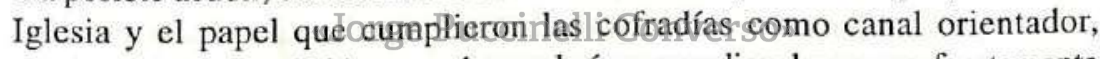
continuando una tradición con raíces en la época medieval europea, fuertemente vinculada a la institución religiosa (Barriga Tello 1994:19 s). Entre la habilidad del religioso en promocionar la constitución de estas agrupaciones cívicoreligiosas que le facilitaran lograr sus fines y el espíritu de competencia que, paralelamente, se encargaba de alentar, propagando entre sus miembros los logros alcanzados por agrupaciones vecinas (Arriaga 1968: Cap. X), estuvo el provecho que obtuvo su Institución. Este fue el mecanismo por el que los indígenas se convirtieron en promotores de obras de arte por intermedio de la Iglesia, bajo su auspicio y en su directo beneficio.

La crítica contemporánea no se hizo esperar frente a esta comprobación. Notaba Hernando de Santillán que en edificar iglesias y adornar templos se presionaba en exceso al indio, "como si no hobiese otro a quien tributar" (Santillán 1968:126), pues necesitando menos, se había llegado a levantar cuarenta iglesias en una provincia, muchas veces para residencia 
esclusivamente de uno o dos frailes (Ibid., 137 y Carta de F. Vicente de Valverde, en: Lissón Chávez 1943-1956: I, N² 2). Esta denuncia no fue aislada, pues la encontramos emitida por miembros de todos los sectores, aunque su persistencia no significó la modificación de la práctica.

Ante la participación de otros grupos sociales nativos, no podía mantenerse al margen la familia real Inca, tanto más cuando su incorporación a la sociedad española fue propiciada por la Corona, como parte de su política de eliminar obstáculos y prevenir posibles insurrecciones.

En los tempranos años del gobierno español en el Perú advertimos varios casos -entre los muchos posibles -en los que participaron indígenas notables. Inca Paullo Topa Yupanqui, hijo de Huayna Cápac y nieto de Tupac Yupanqui fue bautizado en 1543 con el nombre de Cristóbal. Conmemorando su incorporación a la religión cristiana, funđó en el Cusco la capilla de San Cristóbal. En 1560 ésta fue convertida en parroquia de indios (Covarrubias 1958:13). Poco después, en 1563, don Joaquín Tisoc Saire Tupac Inca encargó en el Cusco un lienzo del Señor de la Sentencia el que, posteriormente, fue colocado en la iglesia parroquial de Santiago(Ibid., 153). La nobleza Inca afirmó su presencia en el contexto artístico virreinal desde muy temprano

En el estrato Rocialieutopea en el Perú virreinal existió el mismo impulso. Los españoléseñAméricai,isobre tơdoląuellos que alcanzaron éxito en las diversas expediciones, lograron suficiente solvencia económica como para acceder a una práctica reservada en España solamente para quien contara con los medios económicos y gozara del prestigio social que avalara su ambición: la erección de templos y la constitución de una capellanía en su capilla privada. Las donaciones testamentarias de algunos de ellos especificaban lugar, magnitud, ornamentación y normas generales del culto que se deseaba se ofreciera en ella. La donación se condicionaba a lo que se obtuviera como beneficio.

En su testamento del 8 de julio de 1588 don Diego de Almagro estipuló a sus albaceas que, además de entregar 1,000 pesos de oro al monasterio de Nuestra Señora de la Merced del Cusco para contribuir a la celebración de la fiesta de su titular, "hagan la Iglesia y Convento a su costa, con todos los indios de su repartimiento". Pidió por ello ser enterrado en la Capilla Mayor del templo que se erigiera. La iglesia debía contar con "los correspondientes 
retablos". A lo que añadió "una casulla y dalmáticas de terciopelo negro, tres albas, un cáliz de plata, una cruz de quince marcos de plata, con su manga de terciopelo negro, unas vinajeras e incensario de plata" (Ibid., 92; Vargas Ugarte 1956: II, 121). Aunque pudo sentirse obligado con quienes le brindaron su incondicional apoyo en su controversia con los Pizarro, aquí Almagro también refrendaba su condición de copartícipe del éxito de la empresa americana y sustentaba el honor que por ello le correspondía.

El estamento español de la sociedad estaba estrechamente ligado a la Iglesia. Esta circunstancia, y la acumulación de riqueza que se observaba en gran parte de este sector, resultó en la propagación de la costumbre de instituir capillas privadas en los templos. Tal actitud se adscribe al desarrollo del individualismo del hombre de la época en Europa, a quien se le convirtió en indispensable destacar del promedio y ascender en la escala social. El culto a la "apariencia", que conllevaba "honor y prestigio", irrumpió en la progresivamente más desigual sociedad colonial. El español en América dejaba de estar constreñido al estrato søcial que por nacimiento le correspondía en España. En el nuevo territorio su capacidad, o su astucia, podían convertirlo en acaudalado ciudadano y hasta en noble. Sustentar su adquirido status significó rodearse de elementos connotativos, elitistas. Entre ellos, la promoción o posesión de obras de arte fue primordial como símbolo de poder y nobleza, cuya majestuosidad prestigiaba al fitulae.S

\section{"Jorge Puccinelli Converso"}

Entre las obras acreditadas estuvieron las capillas privadas en las iglesias, en las que coincidían arte, generosidad, dominio, opulencia y fe. Cantidad de ellas se erigieron para servicio de sus poseedores, llegando a constituir espacios independientes, aislados, cedidos bajo convenios detallados a individuos o grupos organizados. Fueron expresión de distinción y reflejo de la capacidad económica del beneficiado. Los contratos que se establecieron entre la Iglesia y los solicitantes mantuvieron un cierto modelo en cuanto a los considerandos. Gran parte de ellos surgieron con posterioridad a disposiciones testamentarias, como el de la capilla erigida en la Catedral de Lima por Francisca Pizarro cumpliendo disposiciones de su padre.

Los españoles que llegaron con Francisco Pizarro, y aquellos que en ocasiones posteriores lograron destacarse del común, recurrieron a tan eficaz medio de divisa social, en el que no descartamos el nivel de persuación de los religiosos, pues también concurrió al éxito de dicha costumbre el arrepen- 
timiento por las acciones de la conquista. Fue el caso - entre otros- de Francisco de Chávez, quien el 7 de setiembre de 1568, y habiendo sido muchos años residente en Arequipa, hizo donación en España a la iglesia de San Martín de Trujillo, en Extremadura, de una capilla en la que todos los martes debía decirse una misa "por los indios christianos naturales de los reinos del Perú, a los que soy en cargo, vivos e difuntos, quiero señor sea servido de los perdonar a los vivos alumbre el entendimiento e los traiga al verdadero conocimiento de la sancta fee catholica" (Porras Barrenechea 1986: 706). O como Mancio Serra, quien prefirió dejar todos sus bienes en donación para lograr redención por su participación en la empresa pizarrista (Ibid., 577).

Se establecieron ciertas diferencias en las modalidades de adjudicación de espacios en iglesias y conventos. Hay oportunidades en las que los religiosos especifican claramente lo que esperan del beneficiario. La Orden Agustina en el Cusco firmó el contrato de donación de la capilla de San José y San Luis junto al altar mayor de su iglesia matriz a Juan Espinoza, Regidor del Cabildo de la ciudad. A cambio debía "fabricar y edificar la dicha capilla y ornarla poniendo en ella un retablo de cedro dorado, dotándola de los ornamentos nercesarios". Además de construir la bóveda que le serviría de entierro, debía pagar por la capilla 3,000 pesos corrientes de a ocho reales el peso y fundar una capellanía de 500 pesos corrientes de renta en cada un año a favor del convento (Vargas Q garte 1956:H,F72: [12.VI.1599]). Es posible que la congregaciónemantuvieral la potestad de decidir sobre aquello que se hiciera, sin delegar derecho.

Diferente situación se presentó con los benefactores de la Compañía de Jesús en el Cusco doña Teresa Orgoñez, familiar del Obispo Vicente de Valverde, viuda del capitán Diego de Silva y Guzmán, conocido personaje de la conquista. Cumpliendo disposiciones testamentarias de su esposo, ella y su hija "hacen fundación y patronazgo, de la Casa y Convento de la Compañía de Jesús... para cuyo efecto hace donación pura y perfecta, de 20,000 pesos de plata ensayada y marcada..., donde el Rector y demás hermanos, han recibido el sustento y comida y regalos y para la iglesia, de ornamentos, órganos, docel para el Altar Mayor, paños para el ornato y otros menesteres religiosos". La condición fue que se permitiese a su linaje el uso de la Capilla Mayor para su enterramiento y que se colocaran las armas de Diego de Silva y de Teresa Orgoñez en el Colegio "en la parte y lugar que les pareciere, las que la Compañía tendrá eternamente, para siempre jamás, 
y nunca de los sucesores" (Ibid.,194). En este contrato es el comitente el que impone las condiciones en proporción a la magnitud de su aporte, aunque la Orden mantiene la potestad de distribuir lo obtenido.

En el primer convenio la responsabilidad del patronato recayó en el donante bajo la vigilancia de la congregación; en el segundo ésta retiene el derecho, al recibir parte de la entrega en bienes y parte en efectivo. Un tercer ejemplo lo tenemos en el caso de dos de las más importantes capillas limeñas. Las de "los Agüero y Aliagas", en la iglesia de Nuestra Señora del Rosario. Ambos donantes actuaron en concordancia y bajo responsabilidad compartida con los dominicos, aceptantes en el contrato.

Estas capillas eran "la primera del Evangelio, y la segunda de la Epístola, fundaciones tan antiguas que comenzaron con la misma iglesia y labraron y dotaron a su costa, y de sus bienes los capitanes Diego de Agüero y Jerónimo de Aliaga de los primeros conquistadores del Reyno y pobladores de Lima, que hoy gozan sus herederos" (Meléndez 1681: Libro I, Cap. VIII). Cuando, por razones de espacio, hubo de modificarse la disposición de la asignada a los Aliaga, el convento, en compensación por la incomodidad que esto suponía, amplió los derechos de la familia, permitiéndole "hacer y poner a la puerta de la dicha Capilla reja de hierro con su cerradura e llave como Señor de ella" (Angulo 1921:541), contolaal se constituyó como propiedad privada intāigible.Puccinelli Converso»

Así comprometidas, las familias continuaron favoreciendo a la iglesia, engalanando las capillas. La viuda de Aliaga contrató un retablo para la suya a Mateo Pérez de Alesio (Stastny 1969:29; Mesa y Gisbert 1972: de Martínez, Diego. 1592, fol.1482 y vta. A.N.P.), que pudo ser el que se adjudicó a Juana de Aliaga, su nieta. De ella se dice que "hizo un retablo al óleo, grande, a proporción de la capilla, con una imagen de la Concepción arriba, que le costó más de tres mil pesos, añadiendo paños de seda para las paredes y ornamentos para el altar" (Lizárraga 1968: Libro I, Cap. XXV). Esta advocación fue la que estuvo en la primera intención de don Jerónimo al fundar su capilla.

Contribución similar hicieron los descendientes de don Diego de Agüero. Su hijo "puso en ella un retablo grande a proporción de la capilla, con un crucifijo de muy buena y devota figura", al que añadió "muchas reliquias 
de santos en sus medallas que le dió el convento" (Ibid., Libro I, Cap. XXIV). Los dominicos, de esta forma, retribuían en parte el gran apoyo que recibieron del fundador cuando llegaron a la ciudad, hecho que demuestra la solidaridad existente entre los estamentos más antiguos de la sociedad virreinal: conquistadores y dominicos unidos en el arte, la devoción y el poder.

Algunas Ordenes llegaron a comprometer la Capilla Mayor, costumbre que fue suspendida por la Corona. La viuda del capitán Gómez Arias era patrona de la Capilla Mayor de la iglesia de San Francisco en Huánuco. En 1566 decidió decorarla con algunas pinturas para lo cual contrató a Juan de Illescas, quien con anterioridad había hecho trabajos para su esposo (HarthTerré 1949). La frecuencia de esta costumbre motivó la disposición real de reservarlas para su uso y paralelamente, limitar el rápido, peligroso y demostrativo ascenso social en los territorios americanos.

La donación de retablos suele estar aparejada a una solicitud, contemporánea o posterior, alenterramuento en la iglesia donde deberá instalarse. Otras veces busca motivar la intervención de los religiosos en los servicios fúnebres y las misas perpétuas por el alma del difunto. Es un recurso menos costoso que una capilla y, para los efectos espirituales, igualmente efectivo. Nicolás de Marchán, madrileño y mercader en la ciudad del Cusco, estipuló en su testamento que se entregarade sus bienes 400 pesos corrientes al convento de

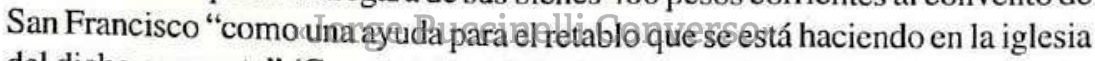
del dicho convento" (Covarrubias 1958: 73). Al año siguiente, 1597, y también por vía testamentaria, Juan Pérez de Prado otorgó poder a su hermano, el franciscano fray Fernando Prado, para disponer de 2,000 pesos de sus bienes y entregarlos a su convento para los gastos de la construcción del mismo retablo (Loc. cit.), que entendemos debió ser el Mayor. El primero de los mencionados adicionó una cantidad de dinero para misas. El segundo solicita que lo entierren en el convento con compañía de frailes, ritual común en la época. El retablo central en las iglesias concita el interés de los donantes, talvez porque no obligaba a asumir totalmente el presupuesto, sino solamente contribuir a cubrirlo. Igualmente en 1593 Alonso Picado cedió la suma que le correspondió como Procurador, a las obras del retablo central en la iglesia de los dominicos en Arequipa, lo que permitió se pudiera hacer el encargo a Mateo Pérez de Alesio (Harth-terré y Márquez Abanto 1963; Vargas Ugarte 1968:129).

Mucho más frecuente fue la donación de ornamentos. La cantidad 
y valor de ellos determinó la exigencia que proponía el comitente. Domingo de Ampuero, vecino del Cusco, testó en 1564 dejando 300 pesos de plata para "la corona de Nuestra Señora de la Merced" (Covarrubias 1958: 95). Donaciones similares son frecuentes en esta ciudad. El capitán Alonso Palomino por su parte, entregó "una copa y casulla de brocatel, dalmáticas y frontales, albas con sus faldones de brocato, una manga de cruz, una capa y casulla de terciopelo verde, tres cálices de plata, un incensario de plata del peso de siete marcos, una lámpara de plata del peso de veinte marcos, un acetre con su esopo del peso de ocho marcos, una cruz de plata labrada del peso de veinte marcos, seis candeleros de plata del peso de dieciseis marcos y dos doceles, uno de terciopelo rosado y bordado y el otro de damasco anaranjado" (Loc. cit.). Lo motivaba el deseo de ser enterrado en la Capilla Mayor de la iglesia de La Merced.

Otra es la inquietud que incentivóla donación de don Jerónimo Pacheco, Tesorero del Virrey y, a su vez, Corregidor del Cusco. Su hijastra había fundado el convento de Nuestra Señora de los Remedios en Arequipa, lo que hizo que él encargara al platero Miguel Morzillo, a la sazón éstante en el Cusco, un retablo para reliquias para donarlo al nuevo monasterio dominico (Harth-terré 1945). Los conventos de monjas, en general, suscitaron amplias donaciones de los familiares de las novicias, lo que los convirtió en instituciones que contaron con grandes rentas que permitierơnonostracantiguēzeènedificios y ornamentos.

\section{"Jorge Puccinelli Converso»}

Continuamente los españoles entregaban objetos votivos a los templos de las diversas Ordenes para ser colocados cerca a la imagen a la que,con éxito, habían solicitado una merced. Una ocasión singular en este sentido dió lugar al surgimiento del santuario mariano de Nuestra Señora de Guadalupe en Pacasmayo.En cumplimiento de una promesa Francisco Lezcano viajó a Sevilla, donde encargó una imagen de la Virgen con esta advocación. De regreso al Perú decidió colocarla en una ermita que puso en manos de los padres agustinos en 1563. A partir de entonces la enriqueció al punto que llegó a convertirse en "el mejor y más suntuoso que había a cien leguas a la redonda y su interior se hallaba adornado de láminas, talladuras y grandes cuadros, representando los principales milagros de la Virgen" (Vargas Ugarte 1956: II, 99ss.). Este lugar se convirtió en centro de peregrinación y de trabajo para los artistas convocados.

La importancia de la Iglesia de España en el Perú durante el período 
virreinal como promotora de obras de arte fue singular. No hubo otra institución oficial que propiciara el desarrollo de las artes como ella permanentemente hizo. Fue un impulso sostenido en tanto igualmente auspiciaba el establecimiento de sus templos y conventos en el territorio peruano, base de su incorporación al gobierno virreinal y de su poder.

Hemos esbozado aquí algunas de las acciones de la Iglesia como auspiciadora y promotora de donaciones de obras de arte religioso. Otra fue su actividad como mecenas, en la que la asumió directamente y de manera corporativa el trato con los artistas. En ambas actividades tuvo éxito en tanto los fines que perseguía, lo que resultó en el amplio patrimonio artístico que le reconocemos hoy.

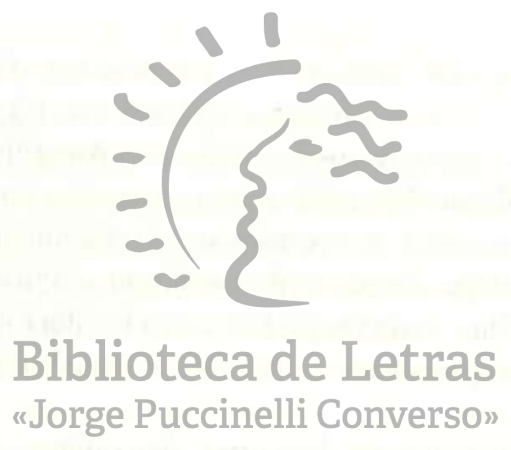




\section{BIBLIOGRAFIA CITADA}

ACOSTA, S.J., Joseph de

[1590] 1954 Historia natural y moral de las Indias. Madrid, Biblioteca de Autores Españoles, T. 73.

ANGULO, O.P.,Domingo.

1921

"Escriptura de la fundación y dotación de la capilla que el Capitán Gerónimo de Aliaga...." Revista del Archivo Nacional del Perú, (Lima) Tomo II, Entrega III.

AREVALO, O.P. José María

1970

Los dominicos en el Perú. Lima, Editorial San Antonio.

ARMAS MEDINA, Fernando de

[1532-1600] 1953 Cristianización del Perú. Sevilla, Escuela de Estudios Hispano-Americanos.

ARRIAGA, S.J., Pablo José

[1621] 1968 Extirpación de la idolatría del Pirú, en Este Barba 1968, 191277 . 1 lioteca de Letras

BARRIGA TELLO, Martha

\section{"Jorge Puccinelli Converso"}

1993

"Relación entre Iglesia y Arte durante el Virreinato del Perú: Aproximación". Letras (Lima, U.N.M.S.M.), 92-93: 108-119.

1994

"Religiosos y el Arte en el Perú sdel siglo XVI". Sequilao (Lima), Año III, 7: 19-32.

BERNALES BALLESTEROS, Jorge.

1991 "La escultura en Lima, siglos XVI-XVIII". En Escultura en el Perú. Banco de Crédito:1- 133. Lima,

CATALOGO de Fondos Americanos del Archivo de Protocolos Sevilla. T. 1, s. XVI. 1930 En Colección de documentos inéditos para la Historia de Hispanoamérica. T. X. Sevilla. 
CORDOBA Y SALINAS, O.M., Fr. Diego de

1958

Teatro de -la Santa Iglesia Metropolitana de los Reyes.

Lima, Biblioteca Histórica Peruana, T. VII.

CORNEJO BOURONCLE, Jorge

1960

Derroteros del arte cuzqueño. Cuzco, Ediciones Inca.

COVARRUBIAS POZO, Jesús M.

1958

Cuzco colonial y su arte. Apuntes para la historia de los monumentos coloniales del Cuzco. Cuzco, Editorial H.G. Rozas.

ESPINOZA SORIANO, Waldemar

1977

La destrucción del Imperio de los Incas. Lima, Retablo de Papel Ediciones.

ESTEVE BARBA, Francisco

1968

Crónicas peruanas de interés indígena. Madrid, Biblioteca de Autores Españoles, T. 209.

HAMPE MARTINEZ, Teodoro

1981

"Lalactuacioncdeldobispotviaente de Valverde en el Perú". Historia yn Eultura (Lima) 13-14: 109-153.

HARTH-TERRE, Emilio

1940

"Vida y obra de los artífices virreinales. Siglo XVI". Mercurio Peruano (Lima), Año XVI, Vol. XXIII, No. 170, mayo.

1945

"Miguel Morzillo". El Comercio, (Lima) 16.V.

1949

"Los Illescas, pintores en Lima". Mar del Sur (Lima), Vol. II, 5, mayo-junio.

HARTH-TERRE, Emilio y Alberto MARQUEZ ABANTO

1963

"Pinturas y pintores en Lima virreinal". Revista del Archivo Nacional del Perú (Lima), Tomo XXVII, Entregas I y II. 


\section{JESUITA ANONIMO}

[1594-1595] 1968 Relación de las costumbres antiguas de los naturales del Pirú. En: Esteve Barba 1968, 151-189.

LISSON CHAVEZ, Emilio

1943-1956 La Iglesia de España en el Perú. Sevilla, Editorial Católica Española. 26 vols.

LIZARRAGA, O.P., Fray Reginaldo de

[1603-1609] 1968 Descripción breve de toda la tierra del Perú,Tucumán, Río de la Plata y Chile. Madrid, Biblioteca de Autores Españoles, T. 216.

MELENDEZ, O.P., Fray Juan

1681

Tesoros verdaderos de Indias en la historia de la gran provincia de San Juan Bautista del Perú, de la Orden de Predicadores. Lima, Imprenta de Nicolás Angel Tinassio.

MESA, José de y Teresa GISBERT

1972

"El pintor Mateo Pérez de Alesio". Cuadernos de Arte y Arqueología (La Paz), $\mathrm{N}^{\circ} 2$.

1974

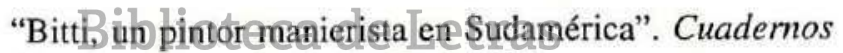
de Arte A A kquelogía (LaPaz) țiso"

MILLONES, Luis

1984

“Taki-Onkoy”. Cielo Abierto (Lima),Vol. X, N 28, abril-junio.

PORRAS BARRENECHEA, Raúl

1951

"Prólogo" a: Domingo de, Santo Tomás, Gramática o arte de la lengua general de los indios de los Reynos del Penú. Lima, Universidad Nacional Mayor de San Marcos. Edición facsimilar.

1986

"Crónicas perdidas, presuntas y olvidadas", en su Los cronistas del Perú, ed. de Franklin Pease G.Y. Lima, Banco de Crédito del Perú.

SANTILLAN, Hernando de 1968

Relación del origen y descendencia, política y gobierno 
de los Incas. En Esteve Barba 1968.

STASTNY, Francisco

1969

"Pérez de Alesio y la pintura del siglo XVI". Anales del Instituto de Arte Americano e Investigaciones Estéticas (Buenos Aires), $\mathrm{N}^{\circ} 22$.

1985

"Una tabla sevillana de la época de la Conquista". El Comercio (Lima), 29. III.

STERN, Steve

1982

"El Taki-Onkoy y la sociedad andina (Huamanga siglo XVI)”. Allpanchis (Cusco), $\mathrm{N}^{\circ} 19$.

VARGAS UGARTE, S.J., Rubén

1956

Historia del culto a María en Iberoamérica y de sus imágenes y santuarios más celebrados. Madrid, Talleres Gráficos Jura.

1963

Los jesuitas en el Perú y el arte. Lima, Librería e Imprenta Gil.

1968

\section{Biblioteca de Letras}

Ensayo de un diecionario desantifices de la América Meridional. 2a. ed. Burgos, Imprenta de Aldecoa. 